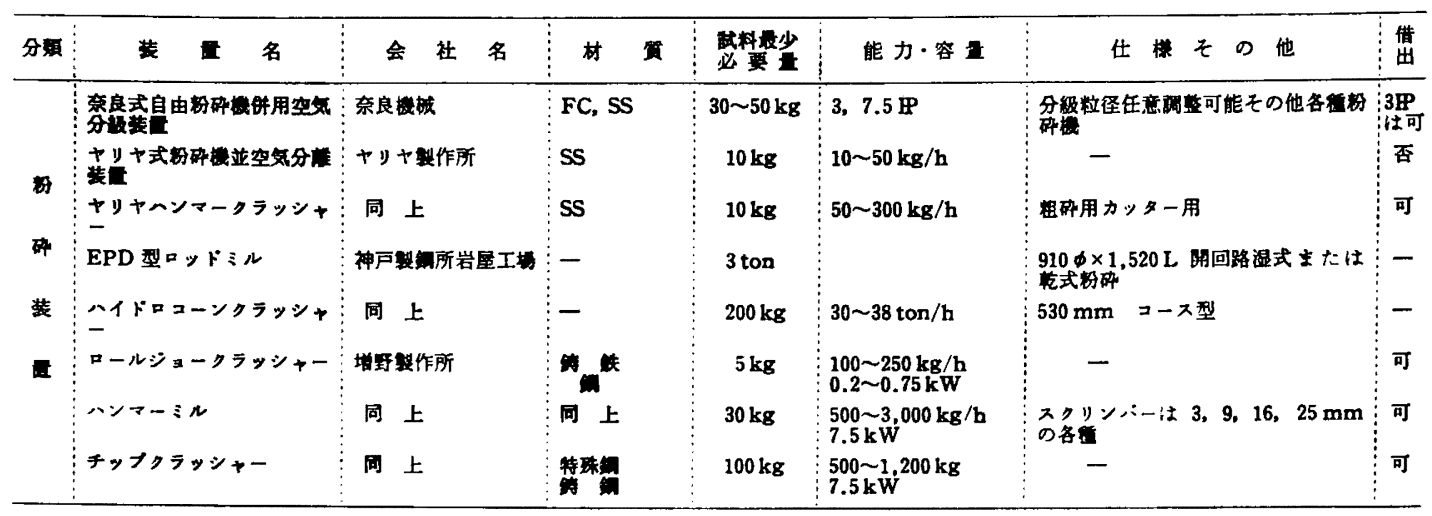

パイロットプラントの 計 装*

山 $\quad$ 直 ${ }^{* *}$

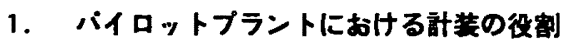

ひと頃のパイロットブラントには，珐力計などほんの 少しの計器がつけられていたにすきなかったが，最近で はかなり進んた計装が行なわれるようになってきた。: イロットフラントを計装する目的はつきの諸点にあると 思われる。

i）短期间化数多くのデータを採集する。

ii）運転条件を被密火する。

iii）ブラントの功特性を求める。

iv） ハイロットブラントの段階で将来必要となる計器を開発 しておく。

v）連転炕要する人員を削縅する。

そしてパイロットブラントにおいて，静特性，動特性 に関する有奻な情報が得られていれば,シミュレーショ ンの手法”などにより精度よいスケールフッブを行なら ことができる。

最近では特にハイロットフララント用として便利な計洣 器も開発されているので, それらのらち計測の三要菜と いわれる流量，温度，圧力について紹介する。いうまで あなく、パロットブラントにおいては特殊な計器る要 求されるが，その際は各位の創意工夫が大切である。

* 昭和 41 年 6 月 2 日 受理

** Sunao Yamashita 味の素(株) 中央研究所

\section{2. 一般的注意事項}

パイロットプラントの計装を行なう䟢留意すべき一般 的注意事項はつきのと括りである。

i）少ない量な取り扱5ので，検出部，操作部もこ れに合致したるのでなければならない。

ii）ちょっとしたこみや気泡です大きな誤差を生ず る原因となるのでここれらの除去につとめねばならな い。

iii）ハイイロットブラントの通転に際しては，静特性 ばかりでなく，動特性の採集にる心卦ける必要がある。

iv）動特性の娜定に用いる検出部の応答は，プロセ スのそれに比へ十分速くなければならない。

v）パイロットブラントでは，実䀦条件の変更が頻 繁に行なわれるので，娜定籍囲などが容易に変えられる ものが望ましい。

vi）データ整理の都合上，得られる偪号は空気また は奄気で統一されているのが便利である。

、ii）防爆，耐圧など安全に対する考甞が足りないこ とが多いので，これらの点を十分注意する。 viii）差支えない限り简易型計器（減圧并，流量調整 


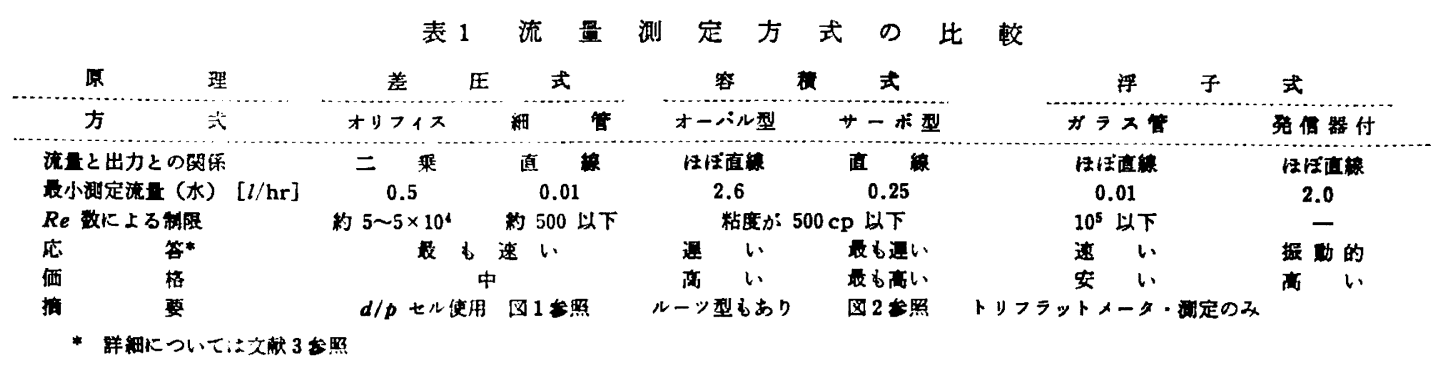

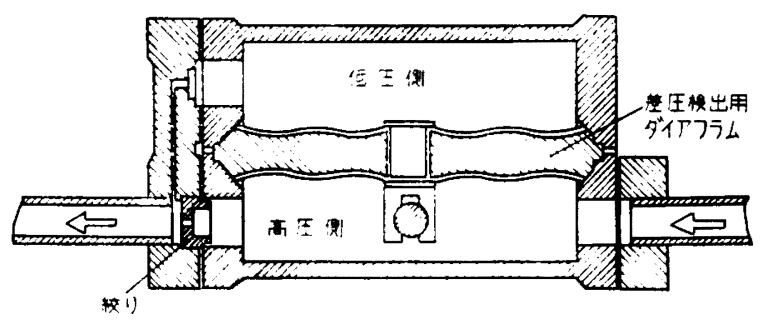

因 1 インテクラルオリフィスd/p七ル断面图 (Foxboro 社)

升など）を用い計装設借費の低減に努力する。

ix）一方コマーシャルブラントに岁いて問題の生じ そうな個所には思いきって計器を投入し，十分な情報を 把握する。

\section{3. 流且の模出法}

\section{$3 \cdot 1$ 各程流且测定方式の比较}

ハイロットブラントの計装において，担当者が最す苦 心するすのの一つに流田の計即がある。たとえば、ハィ ロットブラントの規模が制御可能な流国に上って決定さ れることもしばしば経馀している。

徽小流のフィードには，ミルトンロイなどの定容 ポンブがよく用いられるが，脈流であるのと流旦の指示 が得られないのが欠点である。丧、に微小流量の各程测 定方法を比较したものを示し，以下そのおのおのについ て若干説明する。

\section{$3 \cdot 2$ 童 式}

微小流量における差压を空気圧または電気信号にかえ る発信器としては，図1に示すような絞りを内藏した Integral Orifice $d / p$ Cell (Foxboro 社) が便利であ る。これは流量発信器内を被测定流体が通過している5

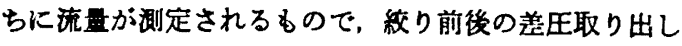
管のないのが特徵であり, $100 \mathrm{~kg} / \mathrm{cm}^{2}$ 程度の耐圧を有す る。絞りの形状としては，四分円ノズル，半円ノズル， す刃オリフィスなどいろいろのるのがあるが, ストレー トオリフィスが最も手怪に得られる。すなわち、ストレ
一トオリフィスは5す板にドリルを用いて孔をあ け，周囲のばりを軽く落すだけでよいから，研究 施設などで筬単に作ることができる。筆者が調へ たところでは2)，孔径とオリフィス板厚をは湆同 一にとった場合, 孔径 $0.3 \sim 4 \mathrm{~m} / \mathrm{m}, R e$ 数 $5 \sim 5$ ×104kわたりほぼ一定の流量係数が得られた。 しかしこの程度の微小流では，流量保数を計算 のみで求めることは難しく, やはり実測が必要と なる。したがって测定籍囲のうちの適当な所で一 点だけ流早を実際にチェックして流量係数を求め ておけば大体 $\pm 3 \%$ 程度の精度が得られる。

さらに㓋小な流量の測定には細管式がよい。細管は被 测定流体が清澄であれば直径 $0.1 \mathrm{~m} / \mathrm{m}$ 程度のものまで 可能であり，たとえば温度計用などのガラス管が利用で きる。 $R e$ 数が 500 をこえると Hagen-Poiseuille の式よ

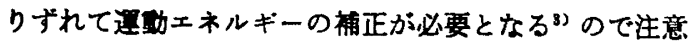
を要する。細管ではもちろん粘度の影管を受けやすいの で，测定中は温度の急变がない上うにせねばならない。 Hagen-Poiseuille の式においては，流量は管径の四乗 に此例するので、管径の測定には特に留意する必要があ ろ。管径はたとえば端面より万能投影譏などで読み取れ ば， $1 / 1,000 \mathrm{~m} / \mathrm{m}$ 程度の测定は可能であるか，面倒であ れば串測によって管径を逆算する方法るある。

一般に差圧式は流体中に含まれるこみ，気泡などによ って大きな㽞差を生じすいから、これらの除去に心措 けねばならない。

\section{$3 \cdot 3$ 浮子式}

ベンチパイロットフランンなどで被测定液自体をマ， メータとした絞り流量計をよく見蛄けが，圧力が高い 埸合つきめから液が噴出して大変危険である。このよ5 なとき，ガラス製の浮子式流量計が用いられる。浮子 式としては各サイズのトリフラットメータ（Fisher \& Porter 社) がセットとして得られるので便利である。 これは，管径 $1 / 16 B \sim 1 / 2 B$ の三角形の断面をるったテ ーバーガラス管の中に，サフフイヤまたはステンレスス ティールのボールを入れたもので，管径および浮子の重 さによって空気なら $0.3 \mathrm{cc} / \mathrm{min} \sim 143.5 \mathrm{l} / \mathrm{min}$ ，水なら 
表 2 温度测定要索の 比較

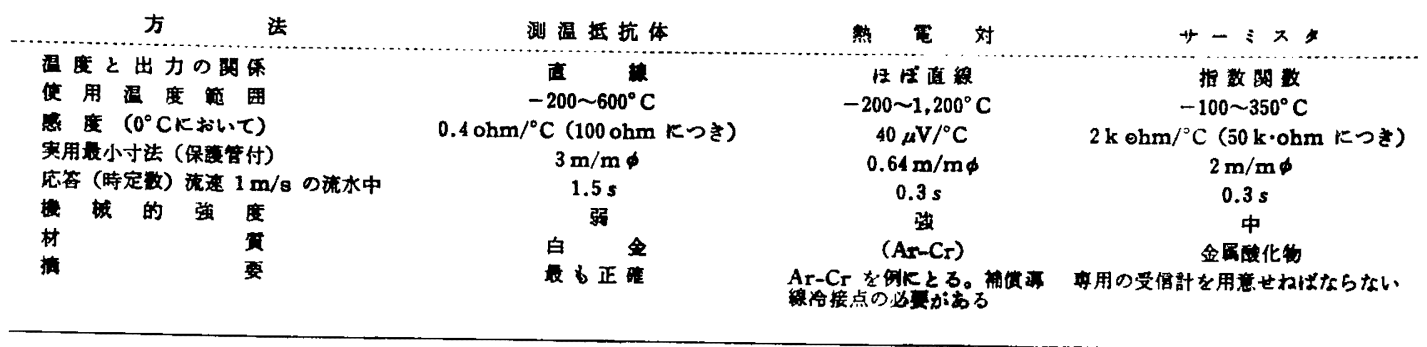

$0.05 \mathrm{cc} / \mathrm{min} \sim 4.4 \mathrm{l} / \mathrm{min}$ の测定筑囲をカパーしている。 またこれらには粘度および密度の補正表すついているの で広く利用できる。

浮子式流量計を流量制御系の検出部として使うには， 浮子の動きを外部にとり出す必要があるのであまり微小 な流量は測定できない。方法としてはマグネットカッブ リングを用いたるのが最す多い。浮子式は被测定流体内 に多少固形物があっても、テーバー管および孚子に付着 しない限りあまり諮差を生じない特街をるっている。

\section{$3 \cdot 4$ 容頵式}

容稑式流量計としては，齒車を用いたオーバル型やル 一ツ型があるが工作精度に限度があるので，微小流化 おいてはすきまからのリークが問題となる。リーク量 は，被測定流体の粘度に反比例するから，粘度の低い流 体および気体は證差が大きくなる。その欠点をおきなう ために開発されたのが图 2 に示すサーボ式流量計であ る。サーボ式では別に設けられたサーボモータによっ て，オーバル型流量計前後の差王がゼロとなるように駆 動するすのである。差殴がぜロとい5ことは、リークが

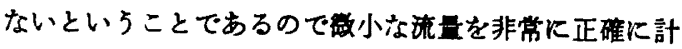
量することができる。

容棈式の特徽は，被测定流体の粘度と測定範囲が適当 であればほほ $\pm 1 \%$ 以内の精度で測定が可能で，碰算值 も同時に得られる。しかし棈造上固形物があると齿車に かみこんで停止してしま5欠点すあるか，他方誤差が生 ビてるかかりにくい差圧式より便利な場合るある。

\section{4. 温度の模出法}

\section{1 各洁温度国定方式の比数}

従来のパイロットブラントにおいては，棒状温度計か; 多く用いられていたが授近では見やすいパィタル型， 夜体胑張型，あるいはサーミスタなど遠隔で測定できる 温度計が用いられるようになってきた。ここでは主とし て, 熱龟対, 抵抗体, サーミスタの三つについて述ヘ る。

パイットブラントにおける温度の湖定法も，流量の

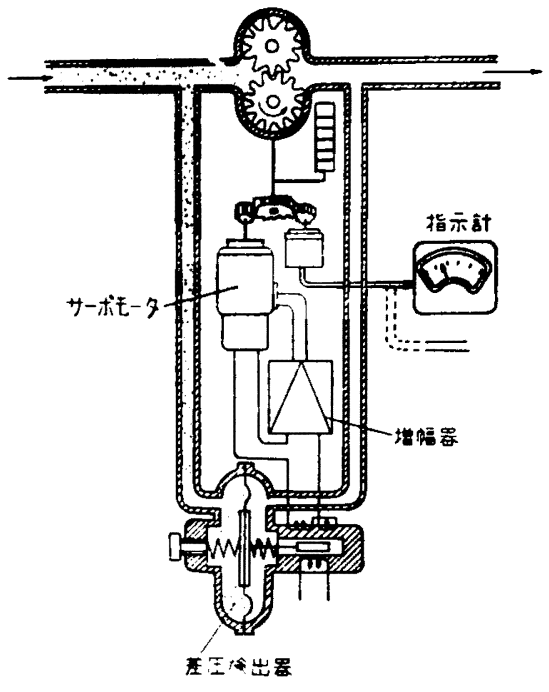

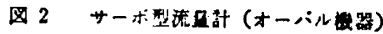

場合と同様に特別な注意が必要となる。まずパイロット ブラントでは，部分の温度を測定することが多いの で，温度の検出部も小さいるのが要求される。ま心一般 にホールドフップす小さいので応答の速い素子でないと 正しい温度変化に追従できない。そのほか外気の影签に よる冷却誤差す生ずるおそれがある。以上を総合すると 装子の選択, 扱入個所の決定, 保設管などの点に留意せ ねばならないことがわかる。

䒾 2 に温度の各植汼定方式を比較したすのを示し、以 下そのおのおのについて若干説明する。

\section{$4 \cdot 2$ 测温抵抗}

高温に使えない欠点があるが，最す安定した测定法で ある。コマーシャルブラント用には直径 $6 \mathrm{~m} / \mathrm{m}$ 以上の すのが用いられるが，ハイロットブラント用として図 3 のよ5に，直径 $3 \sim 4 \mathrm{~m} / \mathrm{m}$ のものが得られる。通常保讙 管に入れて使用されるか，抵抗体との接触をよくしてお かないと応管が幄くなる。

\section{3 然 0 対}

熟角対は古くから温度測定に用いられてきたが， $1^{\circ} \mathrm{C}$ 


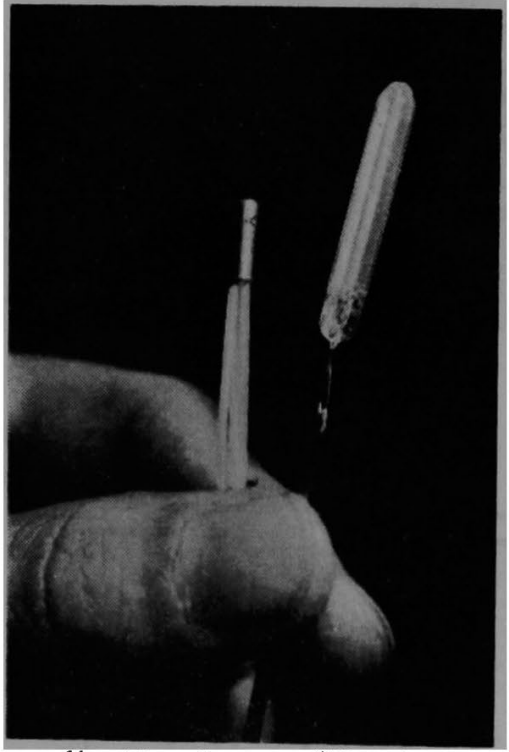

（左：Minco Products 直佳 $3 \mathrm{~m} / \mathrm{m}$

右：富士電機 直经 $5 \mathrm{~m} / \mathrm{m}$ )

图3 小形阘温抵抗体

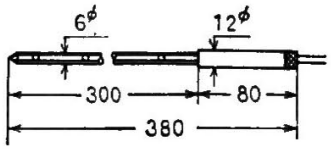

椅型

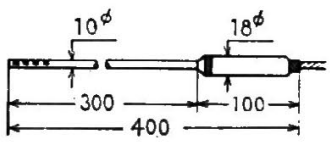

保謨管付奉型

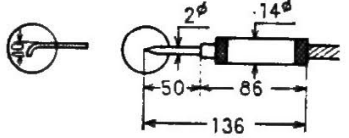

J型

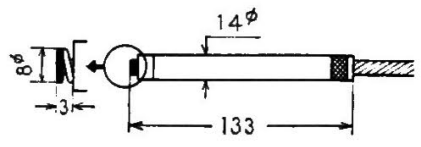

円 板型

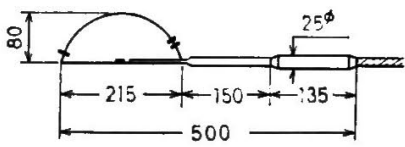

表 面 型

当たりの熱起電力が小さいため, 高温测定用として主に 使われてきた。しかし戦後受信倒である增幅器付電压計 の進歩によって低温用としてもその用途は拡大した。し かし增幅には雑音のレベルによって限度があり, 現在熱 電対で倹出できる温度差は，起電力の大きい鉄-コンス タンタンでもせいぜい $0.1^{\circ} \mathrm{C}(4 \mu \mathrm{V})$ 程度である。

熱電対としては素線を耐熱性の絶縁物の中に埋め込 み，その上にシース（保蒦管のうすいるの）をからせ、 適当な端子をつけた便利なすのが各種市販されている。 通常素線としては，鉄-コンスタンタン，銅ーコンスタン タン，クロメルフルメル，白金-白金ロシュームなど, シース材質としては，ステンレス，銅，白金、ハステロ 1，モリブデンなどの組み合わせが自由に選べる。サイ ズはたとえば AEROPAK (Aero Research 社)では, 外径寸法が 6.64, 10, 1.6, 3.2, 4.8, 6.4, $8.0 \mathrm{~m} / \mathrm{m}$ というようになっていて大変便利である。また気体用と して junction 部が露出したものもあり,特に応答の面 で改善がなされている。たたし junction 部が露出した ものを直接液に捚入すると，異常な電圧を生するので注 意されたい。匤力容器内には、グランド構造によって 挿入されるが，素子自体は $500 \mathrm{~kg} / \mathrm{cm}^{2}$ 程度の耐圧があ る。

熱電対によって正確に温度を測定する場合には補偵尊 線および命接点補猯を行なわねばならないが，最近の計 器では室温補储装圆付のものも多い。

\section{$4 \cdot 4$ サーミスタ}

サーミスタは実験室, ベンチパイロットブラントなど において常温付近の温度を測定するのに好適である。す なわち，微分部分の温度が測定でき，応答も著しく速 い。また抵抗変化が著しいので微小温度差の測定も可能 で、たとえば $0.001 \mathrm{deg}$ の温度差を検出し水車効率の実 測を行なった例”る報告されている。

サーミスタの特性には，姺成のときの条件のばらつき によってなかなか同一のものが得にくいが，最近では補 償回路を組み迈んだものができ，この問題はほぼ解決し た。しかし目盛は非直線なので, 特別な受信計器を用意 する必要がある。サーミスタ先端の構造は，扦入用，表 面温度測定用などの用途によって図4のような形状を選 択することができる。

ガラスサーミスタの出現によって，より高温まで測定 可能のものも得られよ5としている。今後サーミスタは 自己加熱の冷却作用を利用した流量計，液面計などの用 途もあるので㕕く普及するものと考えられる。

\section{5. 王カの模出法}

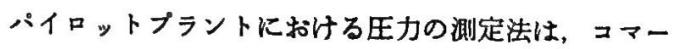
シャルプラントに比べそう変わったところはない。指示 のみの場合は主としてブルドン管，制御または遗隔指示 記録にはこれに空気圧または電子式の発信器を租み込ん だものが用いられる。

ここでは最近特に欧米で多く使用されている金属の受 
氐板にはりつけられたストレインゲージ（歪によって素 線が伸び抵抗が变化することを利用した歪計）による圧 力測定素子を釈介する。通常代の測定範囲は，最小レン $シ シ 0 \sim 0.05 \mathrm{~kg} / \mathrm{cm}^{2}$, 最大 $0 \sim 2,000 \mathrm{~kg} / \mathrm{cm}^{2}$, 使用最高温 度は水冷式ならば $240^{\circ} \mathrm{C}$ までのるのが得られる。因 5 に示すのは常温用の一例であるが国産ではこれょり若干 大型となる。ストレインゲージの抵抗変化はこくわずか であるから, かなり增幅を必要とし, 尃用の受信器を用 いねばならない。近頃はフィリカにおいて軍事用として 半導体による感度の高いストレインメータが開発された とい5。

ストレインメータによる圧力測定の特徴は応答の速い ことで，500 cps の応答に追従できる。このよ5な場合 はむしろ測定器の周波数特性か問題となる。筆者らはあ るパイロットプラントの翼常反応による臥上年をこの 方法で測定し，好結果を得た経験がある。

\section{6. 操 作 部}

\section{$6 \cdot 1$ 微小流量銅蓈弁}

かつてのパイロットブラントでは，簡なオンオフコ ントローラ以外あまり調節器が用いられなかったが, 近 頃ではかなり多くの制御装置がとり入れられるよ5にな り, バイロットブラント用の調節弁も登場してきた。弁 は小形になってくると，工作精度上からありーク量が問 題となり、しかる正しい弁特性（たとえばイコール\%特 性とか平方根特性など）をうることも難しくなってく る。しかし近頃では工作技術の向上によって $C_{v}$ 值 ${ }^{*} 0.05$ 〜0.001のあのすできるようになった。またこれらの升 ではレンジフビリティ** は15 30くらいはとれるので 升全開時の $1 / 15$ 程度の流量まで制御可能である。图 6 に示するのは，特に高圧用として開発された調節弁で約 $300 \mathrm{~kg} / \mathrm{cm}^{2}$ の涌王を有し，并ボジショナも必要に応し て頂部に取り付けることができるよ5になっている。

また場合によっては，調節并なしで微小な量を制御で きる方式》るある。たとえば流量制御に，この原理を応 用した例を图7に示す。すなわち、フィードすくき流体 を密閉した槽の中に入れ, 空気圷式調節器の出力空気圧 を槽の上部に加える。流量が目標値より少なければ調節 器より空気が送り出されて槽内の圧力は上升して押し出 す量がふえ，多ければその逆となる。筆者はこの方式と 細管による差圧式流量発信器を用いて, 清水を $0.14 \mathrm{cc} /$ min の流量で，およそ 10 日間安定に制御した経験があ

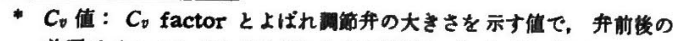
座王か: 1 p.s.i.のとをに流九る水の流量を G. P. M. (gallon per minute) で表わしたいのである。

**Vンジフビリティ：定められた升特性に道合する籍用の最大流量と

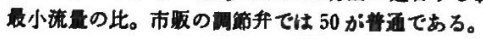

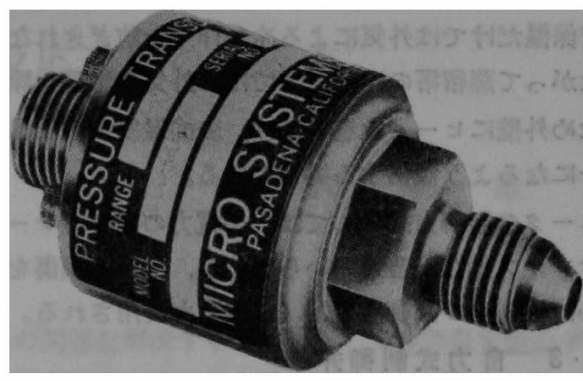

因 5 ストレインダージ利用した圧力発但器 (Micro System 社, $30 \mathrm{~m} / \mathrm{m} \phi \times 40 \mathrm{~m} / \mathrm{m}$ )

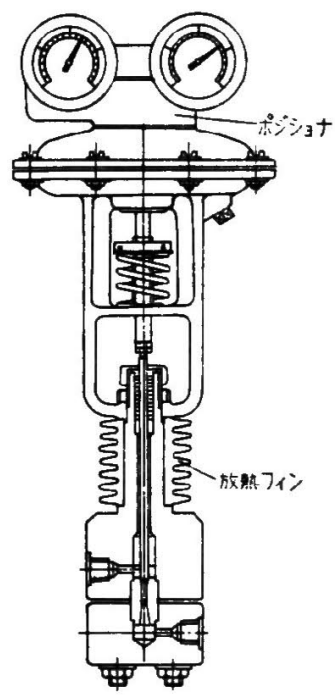

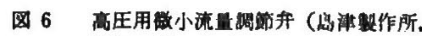
高さ $125 \mathrm{~m} / \mathrm{m}$ )

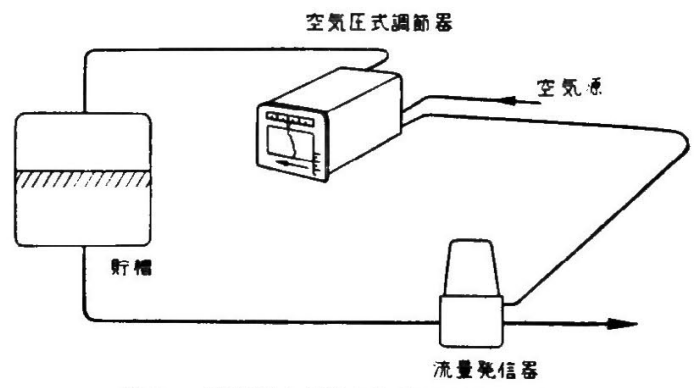

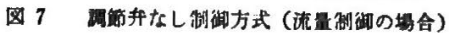

る。

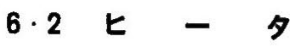

ハイロットブラントに拔ける温度制御の加熱源として は，防爆を要する場合を除き電気ヒータが便利である。 槽には投げ迈み式ヒータ，管または塔にはテーブヒータ やケーフルヒータが用いられる。パイロットブラントに 
おける各装置は，ホールドフップに比へ表面樻が大きい ので保温たけでは外気による冷却作用を防ききれない。

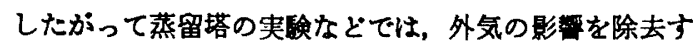
るため外壁にヒータを巻きつけ，表面温度と内部温度が 同一火なるよ5制御する場合もある。

ヒータの制御方式としては，小奄力の場合リレーによ るオンオフ動作が普通用いられるが，接点の損伤を防ぐ ため, シリコン制御整流器 (SCR) む使用される。

\section{$6 \cdot 3$ 自力式制彻井}

パイロットブラントに和ける計装に要する経费を安価 に扰さえる効果的な手段として，自力式の制御弁を上手 に使了方法がある。自力式制御弁は，たとえば空調用な どに多数発売されているが，精度すあまり良好でなく， 信頼性す低いるのが多い。これらをプロセスにすちこむ には十分品筫を吟味して採用せねばならない。

筆者の経险では流量制御弁，減圧弁，温度調整升など の一部には，十分実用に供しらろものがあった。

\section{7. むす ひ}

パイロットプラントにおけす計装の要点は, 常にスケ ールフップを心郝けるいうことになる。粉体の取り扱 いを例にとれば，ハイロットプラントではバヶッに入れ て科にのせて計量し問題はなかったが, コマーシャルブ ラントでホッパースケールを採用したところ粉体が飛散 して大改造のやむなきに至ったことるある。開発担当者 はたえず将来のブラントの形態を予測し，それから間題 点を洞察する能力を蚨成することが重要である。

\section{文落}

1) Yamashita, S.: Preprint Symposium, Industrialization of Reeearch Works (1966)

2) Yamashita, S.: J. of the Society of Instrument and Control Eng., J, 970 (1963)

3) Yamashita, S.: Automation (Japan), 8, 14 (1964)

4) I wanaga, M.: J. of the Society of Instrument and Control Eng., 4, 11 (1961)

5) Japan Patent. No. 224607

[特集終わり]

\section{必要にして稍々不十分}

パイロットフラント実硂を释て設計した新しい車綂プロ 二スの工场が完成して，その武式枟を行なってみた結果, はじめからトラブルがなくドンビシャリとデザイン通りの 品留・収率および能力が出るといらのはわれわれなミかル ニンジニフの理想であり苯であります。

「必要にして十分な」条件を满足する工场の設計を行な ろためにこそ PILOT PLANT 实跧の意数があるわけ です。

しかしこの「十分な条件」を满足するためには、いか に多くの習熱したエンジニフと，期間と，金と，設满と，

設計上の安全率をかけなければならないかを考えてみる必 要があります。

工场をつくって制品の品筫ははじめから孛れるるのが出 なければなりません。工域を一年間通枟しますと収事はデ ザイン以上に上り，能力るまた設計以上に上年してきま す。一方完照と思っていた蔨所に数多くのトラブルが生じ てきます。

はじめからドンピシャリの工场は，一年後には多くの無
䭾がなされていたことるかかってきます。

そこで一度，「必要にして桷不十分な設計」をすること に䫝を切り替えてみることを捛すすめします。

この頭の切り替えによって，BASIC DESIGN, DETAIL DESIGN および機器紫作時の安全率の重被が 多くさけられます。

そして PILOT PLANT 実唤と設計を行なったニンシ ニフを試遇轻啳も引きつつき 1 年間位, その新しい工塨の 实縢の運転に徒事させてみて「十分な DESIGN」Kいか に烸䭾が多いか,「必要な DESIGN」がいかに多く不足 しているか体唤させてみることが必要です。

暖局のきいた居心地の良い部屋で，きびしい冬山の「必 要にして十分な」装傮の設部をすることははとんど不可能 です。「必要にして稍ネ不十分な」売借で冬山に送り出し

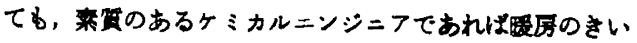
た部屋では考え出せない対策を打ち出してトラブルを解决 して行くことができす。

[O. A.] 